\title{
KRAS Exon 2 Mutation
}

National Cancer Institute

\section{Source}

National Cancer Institute. KRAS Exon 2 Mutation. NCI Thesaurus. Code C135715.

A molecular genetic abnormality indicating the presence of a mutation in exon 2 of the KRAS gene. 